\title{
Nitrogen Fixation by the Green Photosynthetic Bacterium Chloropseudomonas ethylicum
}

\author{
By M. C. W. EVANS AND R. V. SMITH \\ Department of Botany, University of London, King's College, \\ 68 Half Moon Lane, London S.E. 24

\section{(Accepted for publication I7 November 1970)}

Nitrogen fixation by autotrophic green photosynthetic bacteria of the genus Chlorobium was first demonstrated by Lindstrom, Tove \& Wilson (1950). We have now shown that the green heterotrophic photosynthetic bacterium Chloropseudomonas ethylicum can also grow with $\mathrm{N}_{2}$ as nitrogen source. The mechanism of nitrogen fixation by green bacteria has not been investigated and extracts with nitrogenase activity have not previously been prepared from this group of bacteria.

Chloropseudomonas ethylicum strain N2, obtained from Dr N. Kondratieva, was grown in a modified Pfennig's medium with ethanol as substrate as described previously (Evans, I968). For growth under nitrogen-fixing conditions, ammonium chloride was omitted and the medium gassed with $95 \%$ nitrogen, $5 \%$ carbon dioxide. Chloropseudomonas ethylicum has been subcultured continuously for up to 3 months under these conditions. Growth was initiated by employing a $5 \%$ inoculum of a $\mathrm{N}_{2}$ grown culture, and after $48 \mathrm{~h}$. growth the organisms were harvested with a continuous flow centrifuge. The paste was stored frozen until required.

Frozen paste was suspended $\mathrm{I}: 2(\mathrm{w} / \mathrm{v})$ in $0.02 \mathrm{M}$-tris- $\mathrm{HCl}(\mathrm{pH} 7 \cdot 3)$. The buffer was deoxygenated by bubbling with $\mathrm{N}_{2}$ before use. The suspension was cooled in ice under argon for $5 \mathrm{~min}$. and exposed to sonic oscillation under an atmosphere of argon or nitrogen using a Dawe Soniprobe on setting 8 for ro min. The broken suspension was centrifuged for $30 \mathrm{~min}$. at $150,000 \mathrm{~g}$ av. and the clear brown supernatant used as the crude extract without further treatment.

In some experiments oxygen-free $0.02 \mathrm{M}$-tris- $\mathrm{HCl} \mathrm{pH} 7.3$ containing $0.25 \mathrm{M}-\mathrm{NaCl}$ was used. Ferredoxin was removed by passing these extracts through an anaerobic $2 \times \mathrm{I} \cdot 5 \mathrm{~cm}$. column of DEAE cellulose equilibrated with the same buffer. Two $\mathrm{ml}$. of an $0 . \mathrm{I} \mathrm{M}$ solution of $\mathrm{Na}_{2} \mathrm{~S}_{2} \mathrm{O}_{4}$ in the buffer were passed through the column to remove oxygen before the extract was introduced. Chlorophyll-containing particles were prepared essentially as described for particles from Chlorobium thiosulfatophilum (Evans \& Buchanan, 1965).

Enzyme reactions were carried out in $7.0 \mathrm{ml}$. glass vials sealed with Suba Seal rubber caps under an atmosphere of argon at $30^{\circ}$ in a shaking water bath, and stopped by the injection of $0.1 \mathrm{ml}$. of $60 \%$ perchloric acid. Nitrogenase activity was assayed by measuring the reduction of acetylene to ethylene (Dilworth, I966). Ethylene formation was estimated by gas chromatography using a $6 \mathrm{ft} \times \frac{1}{4} \mathrm{in}$. column of Poropak R in a Perkin Elmer FII or Varian Aerograph 1400 gas chromatograph with a flame ionization detector. Ferredoxin was prepared essentially as described previously (Evans, Hall, Bothe \& Whatley, 1968). Preparations used in these experi- 
ments had extinction $390 / 280$ ratios greater than 0.6 . Protein was estimated by the phenol method, as modified by Rabinowitz \& Pricer (1962).

Chloropseudomonas ethylicum grew with $\mathrm{N}_{2}$ as sole nitrogen source. Nitrogen-fixing activity by intact organisms reached a maximum of approximately $28 \mathrm{nmoles}$ ethylene/ $\mathrm{ml}$. of suspension $/ \mathrm{min}$. $50 \mathrm{~h}$. after transfer of ammonia-grown organisms to medium free of combined nitrogen. Nitrogen-fixing ability of intact organisms depended on light; acetylene reduction in the dark was less than $10 \%$ of that in the light.

Untreated soluble extracts of Chloropseudomonas ethylicum catalysed the reduction of acetylene to ethylene (Table $\mathrm{I} a$ ) in a reaction requiring a low potential reductant (sodium dithionite or pyruvate), ATP and an ATP-generating system. When pyruvate was used as reductant the rate of acetylene reduction was considerably stimulated by the addition of coenzyme $A$. The rate of acetylene reduction with pyruvate as electron donor was consistently higher than with dithionite. There was not an absolute requirement for the ATP-generating system with pyruvate as electron donor; presumably some ATP was synthesized as a result of pyruvate oxidation by the phosphoroclastic system. After treatment of the crude extract with DEAE cellulose to remove ferredoxin, the pyruvate-dependent nitrogenase activity became dependent on added ferredoxin. Ferredoxin can be photo-reduced by chlorophyll-containing particles from green bacteria (Evans \& Buchanan, 1965). Acetylene reduction with ferredoxin photo-reduced by chlorophyll-containing particles prepared from C. ethylicum required ATP, an ATP-generating system, $\mathrm{MgCl}_{2}$, ferredoxin, the particles and light (Table $\mathrm{I} a$ ). We could not obtain photophosphorylation with these particles and so could not dispense with the ATP-generating system. The rate of acetylene reduction using the particles was similar to that with dithionite with equal amounts of nitrogenase. The particles could be replaced in this system by illuminated spinach chloroplasts, which confirmed that the role of the particles was the photo-reduction of ferredoxin. Although there was no absolute requirement for ferredoxin when dithionite was used as electron donor, ferredoxin from C. ethylicum stimulated the rate of acetylene reduction by DEAE-treated extracts three- to fourfold; the effect on untreated extracts varied according to their nitrogenase activities. Table I $(b)$ shows the effect of ferredoxins from different sources on acetylene reduction by DEAEtreated extracts. Ferredoxin prepared from $C$. ethylicum grown with ammonia as nitrogen source stimulated the activity three- to fourfold. Ferredoxins from the purple photosynthetic bacterium Chromatium and from the anaerobic bacterium Clostridium pasteurianum were less effective than that from $C$. ethylicum, giving a $50 \%$ stimulation; spinach ferredoxin had no effect and methyl viologen was inhibitory.

From these data it appears that the nitrogenase system from Chloropseudomonas ethylicum is similar to those of other bacteria. (Hardy \& Burns, I968). It requires a low potential reductant (supplied as sodium dithionite or reduced ferredoxin), ATP and an ATP-generating system.

The ability of the enzyme system to use reduced ferredoxin is similar to the Clostridium pasteurianum system, in which ferredoxin reduced by the phosphoroclastic system can be used as electron donor. (Carnaham, Mortenson, Mower \& Castle, 1960). Ferredoxin may be reduced by two enzyme systems from Chloropseudomonas ethylicum, namely that which oxidizes pyruvate and the photochemical system. It seems unlikely that pyruvate oxidation is physiologically important during growth 
Table I. Amounts of ethylene formed by reduction of acetylene by extracts of Chloropseudomonas ethylicum (a) under different conditions and (b) with $\mathrm{Na}_{2} \mathrm{~S}_{2} \mathrm{O}_{4}$ as electron donor and with different ferredoxins

(a) The complete reaction mixturecontained, in a final volume of $\mathrm{I} \cdot 5 \mathrm{ml}$ : : K Hepes $(\mathrm{pH} 7 \cdot 3)$, $100 \mu$ moles; ATP, I ० $\mu$ mole; creatine phosphate, Io $\mu$ moles; creatine kinase, $50 \mu \mathrm{g}$.; $\mathrm{Na}_{2} \mathrm{~S}_{2} \mathrm{O}_{4}, 5 \mu \mathrm{moles} ; \mathrm{MgCl}_{2}$, $5.0 \mu$ moles; and Chloropseudomonas ethylicum soluble fraction containing $3.0 \mathrm{mg}$. protein. When pyruvate was used as electron donor $\mathrm{Na}_{2} \mathrm{~S}_{2} \mathrm{O}_{4}$ was omitted and $50 \mu$ moles $\mathrm{Na}$ pyruvate and $0.125 \mu$ mole coenzyme $A$ were added. When particles were used as electron donor $\mathrm{Na}_{2} \mathrm{~S}_{2} \mathrm{O}_{4}$ was omitted and $20 \mu$ moles 2 -mercaptoethanol, $200 \mu \mathrm{g}$. C. ethylicum ferredoxin and C. ethylicum particles containing $5.0 \mathrm{mg}$. of chlorophyll were added. Illumination $5000 \mathrm{lux}$. Gas phase $90 \% \mathrm{~A}, 10 \% \mathrm{C}_{2} \mathrm{H}_{2}$. After incubation for $20 \mathrm{~min}$. at $30^{\circ}$ the reaction was stopped by injecting $0 . \mathrm{I} \mathrm{ml.} \mathrm{of} 60 \% \mathrm{HClO}_{4}$ through the Suba Seal cap.

Treatment $\overbrace{\text { Dithionite }}^{\begin{array}{c}\mathrm{C}_{2} \mathrm{H}_{4} \text { formed (nmoles) } \\ \text { Electron donor }\end{array}}$

Complete, light

Complete, dark

Electron donor omitted

ATP omitted

Creatine phosphate and

Dithionite

Pyruvate

particles

creatine kinase omitted

$\begin{array}{rrr}- & - & 272 \\ 403 & 665 & 0 \\ 2 & 20 & - \\ 19 & 96 & 0 \\ 44 & 320 & 0 \\ 8 & 36 & 12 \\ - & 124 & - \\ - & - & 136 \\ 0 & - & 0 \\ - & - & 24\end{array}$

(b) The procedure was as in (a), except that DEAE-treated extract contained $3.0 \mathrm{mg}$ of protein, and $200 \mu \mathrm{g}$. of each ferredoxin or $\mathrm{I} \cdot 0 \mu$ mole of methyl viologen was added as indicated.

$\mathrm{MgCl}_{2}$ omitted

CoA omitted

Mercaptoethanol omitted

Extract omitted

Particles omitted

Ferredoxin omitted

$\mathrm{C}_{2} \mathrm{H}_{4}$ formed
(nmoles)
122
435
192
170
112
II

Minus ferredoxin

Treatment

Chloropseudomonas ethylicum ferredoxin

Chromatium ferredoxin

272
0

-

O

Clostridium pasteurianum ferredoxin

Spinach ferredoxin

Methyl viologen

I I

on two carbon substrates, as it is synthesized by the reductive carboxylation of acetate under these conditions (Callely, Rigopoulos \& Fuller, I968; Evans, 1968). It may, however, be important during growth on other substrates. During growth on two-carbon substrates or autotrophically ferredoxin is probably reduced photochemically, and we have shown that a particle preparation from C.ethylicum will catalyse a light-dependent ferredoxin reduction which can then be coupled to nitrogenase. Yoch \& Arnon (1970) have shown that in extracts of the purple bacterium Chromatium ATP required for nitrogen fixation can be generated photochemically by photophosphorylation, but they did not demonstrate light-dependent nitrogen fixation with their preparations.

The marked stimulation by Chloropseudomonas ethylicum ferredoxin of the rate of acetylene reduction of DEAE-treated extracts (with dithionite as electron donor) 
was unexpected, as no stimulation by ferredoxin was observed in a similar experiment with Clostridium pasteurianum nitrogenase (Burns, 1965). If its function were simply to catalyse the transfer of electrons from dithionite to nitrogenase, other ferredoxins, such as those from $\mathrm{Cl}$. pasteurianum or Chromatium might be expected to be equally effective. The apparent specificity for $C$. ethylicum ferredoxin shown by the nitrogenase suggests that it may form an integral part of the nitrogenase complex in this organism.

\section{REFERENCES}

BURNS, R. C. (1965). ATP-dependent hydrogen evolution by cell-free preparation of Clostridium pasteurianum. In Non-Heme Iron Proteins, pp. 289-298. Edited by A. San Pietro. Yellow Springs, Ohio: Antioch Press.

Carnaham, J. E., Mortenson, L. E., Mower, H. P. \& Castle, J. E. (1960). Nitrogen fixation in cell-free extracts of Clostridium pasteurianum. Biochimica et biophysica acta 44, 520-535.

Dallely, A. G., Rigopoulos, H. \& Fuller, R. C. (1968). The assimilation of carbon by Chloropseudomonas ethylicum. Biochemical Journal ro6, 6I 5-622.

DillWORTH, M. J. (1966). Acetylene reduction by nitrogen-fixing preparations from Clostridium pasteurianum. Biochimica et biophysica acta 127, 284-294.

Evans, M. C. W. (1968). Ferredoxin-dependent synthesis of $\alpha$-ketoglutarate and pyruvate by extracts of the green photosynthetic bacterium Chloropseudomonas ethylicum. Biochemical and Biophysical Research Communications 33, 146-150.

Evans, M. C. W. \& Buchanan, B. B. (1965). Photo-reduction of ferredoxin and its use in carbon dioxide fixation by a subcellular system from a photosynthetic bacterium. Proceedings of the National Academy of Sciences of the United States of America 53, 1420-1425.

Evans, M. C. W., Hall, D. O., Bothe, H. \& Whatley, F. R. (1968). The stoicheiometry of electron transfer by bacterial and plant ferredoxins. Biochemical Journal Iro, 485-489.

Hardy, R. W. F. \& BuRns, R. C. (1968). Biological nitrogen fixation. Annual Review of Biochemistry 37, 33I-356.

HARDY, R. W. F., Holsten, R. D., JACKson, E. K. \& BuRns, R. C. (1968). The acetylene-ethylene assay for $\mathrm{N}_{2}$ fixation: laboratory and field evaluation. Plant Physiology 43, I I 85-I 207.

Lindstrom, E. S., Tove, S. R. \& Wilson, P. W. (1950). Nitrogen fixation by the green and purple sulphur bacteria. Science, New York $\mathrm{x12}$, 197-198.

Rabinowitz, J. C. \& PRICER, W. E. (1962). Formyltetrahydrofolate synthetase. I. Isolation and crystallization of the enzyme. Journal of Biological Chemistry 237, 2898-2902.

Yoch, D. C. \& ARnon, D. I. (1970). The nitrogen-fixation system of photosynthetic bacteria. II. Chromatium nitrogenase activity linked to photochemically generated assimilatory power. Biochimica et biophysica acta 197, 180-184. 